\title{
Pathophysiology of communicating hydrocephalus in two novel animal models
}

\author{
Jie Li ${ }^{1}$, Yimin Shen ${ }^{1}$, Janet M Miller*1, Michael R Egnor ${ }^{2}$, Mark Wagshul², \\ Curt Stewart ${ }^{3}$, E Mark Haacke ${ }^{1}$, Marion E Walker ${ }^{4}$, Steven D Ham ${ }^{1}$ and \\ James P McAllister ${ }^{1}$
}

Address: ${ }^{1}$ Wayne State University, 550 East Cranfield, 048 Lande MRB, Detroit, MI 48201 USA, ${ }^{2}$ Neurosurgery/HSC T12-080 SUNY, State University of New York, Stony Brook, NY 11794-8122 USA, ${ }^{3}$ P.O.Box 5402, Carefree, AZ 85377, USA and ${ }^{4}$ Department of Neurosurgery, Primary Children's Hospital, 100 N. Medical Drive, Salt Lake City, UT 84113, USA

Email: Janet M Miller* - jmiller@med.wayne.edu

* Corresponding author

from 50th Annual Meeting of the Society for Research into Hydrocephalus and Spina Bifida Cambridge, UK. 30 August - 2 September 2006

Published: 21 December 2006

Cerebrospinal Fluid Research 2006, 3(SuppI I):S2I doi:I0.I I86/I743-8454-3-SI-S2 I

(C) $2006 \mathrm{Li}$ et al; licensee BioMed Central Ltd.

\section{Background}

Communicating hydrocephalus $(\mathrm{CH})$ occurs frequently but clinically-relevant animal models amenable to diagnostic imaging and cerebrospinal fluid shunting do not exist. This deficiency has inhibited our understanding of the pathophysiology of $\mathrm{CH}$, which may be quite different from obstructive hydrocephalus. The purpose of this study was to perfect two novel models of $\mathrm{CH}$ and to characterize the histopathology that occurs in each.

\section{Materials and methods}

Two methods were employed using 25\% kaolin or saline injected into the sub-arachnoid space (SAS). For injections into the basal cisterns $(\mathrm{n}=7)$, after anterior exposure of the C1-clivus interval, a blunt 30-36 gauge needle was advanced into the SAS and $20-50 \mu \mathrm{l}$ of kaolin was injected. For the cortical approach $(n=9)$, a craniotomy was created over both cerebral hemispheres, and a curved, blunt tip 25G needle was advanced gently into the SAS. After separating the partitions in the SAS, a total of 50-60 $\mu \mathrm{l}$ of kaolin was injected. Animals were sacrificed after chronic ventriculomegaly had developed, and the brains analyzed for cytoarchitectural changes, astrocytosis, microgliosis, neuron death, and axonal degeneration.

\section{Results}

All rats with kaolin injections appeared relatively normal, but preliminary motor learning testing showed transient neurological deficits. In rats with ventral brainstem injections, kaolin was observed grossly in the basal cisterns, but not into the cerebello-pontine angle, indicating that communicating - not obstructive - hydrocephalus had been induced. MRI studies with gadolinium injections into the lateral ventricle confirmed these findings. MRI also revealed that ventriculomegaly progressed steadily in $86 \%$ of these animals and in 2-14 days post-kaolin the mean Evan's ratio (0.43) increased significantly. In rats with cortical injections, kaolin covered approximately $80 \%$ of the hemispheres, and $89 \%$ developed mild protracted (4 months) ventriculomegaly (mean Evan's ratio 0.39 ) not significantly different from controls. In the periventricular white matter, the number of reactive astrocytes and microglia increased only after basal cistern injections. No degeneration of neuron cell bodies was noted in either injection group, but axonal degeneration was present in the periventricular white matter after basal cistern obstruction. These cytological changes correlated with the severity of ventriculomegaly. 


\section{Conclusion}

These preliminary results suggest that $\mathrm{CH}$ can be induced with blockage of the cortical SAS and basal cisterns, that ventriculomegaly is much more protracted in the former model, and the time course of hydrocephalus correlates with the extent of cytological damage. Ongoing studies will help reveal why the time course of ventriculomegaly is so different in these two models.

Publish with Bio Med Central and every scientist can read your work free of charge

"BioMed Central will be the most significant development for disseminating the results of biomedical research in our lifetime. " Sir Paul Nurse, Cancer Research UK

Your research papers will be:

- available free of charge to the entire biomedical community

- peer reviewed and published immediately upon acceptance

- cited in PubMed and archived on PubMed Central

- yours - you keep the copyright

Submit your manuscript here:

http://www.biomedcentral.com/info/publishing_adv.asp 